2. To: (Receiving Organization)

TWRS/TOP

5. Proj./Prog./Dept./Div.:

TWRS, 71220

8. Originator Remarks: $N / A$
3. From: (Originating Organization) TWRS, Process Design 6. Cog. Engr.:

J. D. Galbraith, 376-7929

R. J. Parazin, 376-6196
4. Related EDT No.:

$N / A$

7. Purchase Order No.:

$N / A$

9. Equip./Component No.:

$\mathrm{N} / \mathrm{A}$

10. System/Bldg./Facility:

N/A

12. Major Assm. Dwg. No.: $N / A$

13. Permit/Permit Application No.: $N / A$

14. Required Response Date: N/A

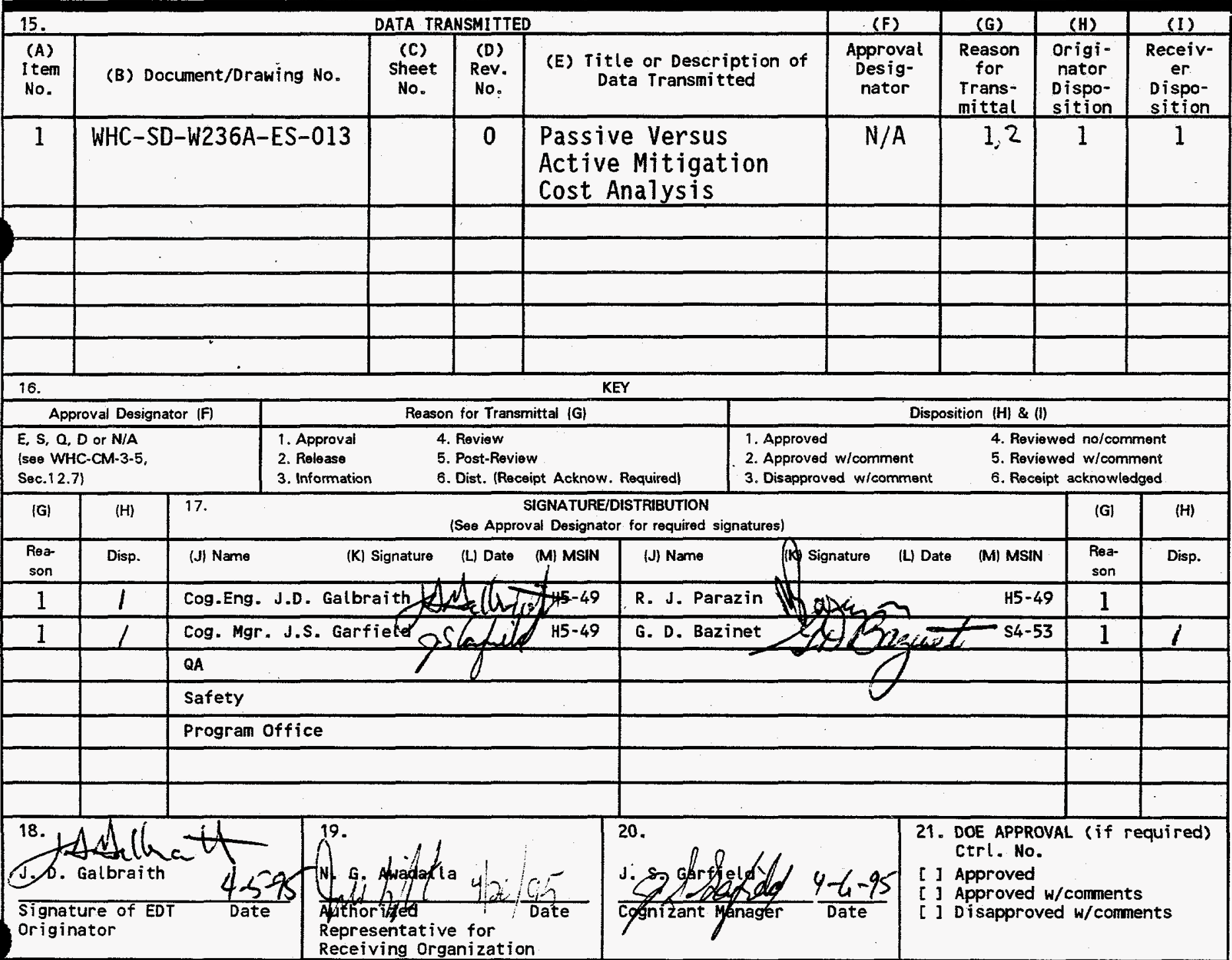




\section{INSTRUCTIONS FOR COMPLETION OF THE ENGINEERING DATA TRANSMITTAL}

(USE BLACK INK OR TYPE)

\begin{tabular}{|c|c|}
\hline$\frac{\text { BLOCK }}{(1)^{*}}$ & $\frac{\text { TITLE }}{\text { EDT }}$ \\
\hline (2) & To: (Receiving Organization) \\
\hline (3) & From: (Originating Organization \\
\hline (4) & Related EDT No. \\
\hline$(5)^{*}$ & Proj./Prog./Dept./Div. \\
\hline$(6)^{*}$ & Cognizant Engineer \\
\hline (7) & Purchase Order No. \\
\hline$(8)^{*}$ & Originator Remarks \\
\hline (9) & Equipment/Component No. \\
\hline$(10)$ & System/Bldg./Facility \\
\hline (11) & Receiver Remarks \\
\hline (12) & Major Assm. Dwg. No. \\
\hline (13) & Permit/Permit Application No. \\
\hline (14) & Required Response Date \\
\hline
\end{tabular}

(15)* Dsta Transmitted
(A)* Item Number
(B)* Document/Drawing No.
(C) * Sheet No.
(D) * Rev. No.
(E) Title or Description of Data Transmitted
(F) - Approval Designator
(G) Resson for Transmittal
(H) Originator Disposition
(I) Receiver Disposition

(16) Key

(17) Signature/Distribution

(G) Reason
(H) Disposition
(J) Name
$($ K) Signature
$(\mathrm{L})$ Date
(M)* MSIN

(18) Signature of EDT Originator

(19) Authorized Representative
for Receiving Organization

(20) $)^{*}$ Cognizant Manager

(211* DOE Approval
- Pre-assigned EDT number.

- Enter the individual's name, title of the organization, or entity (e.g.. Distribution) that the EDT is being transmitted to.

- Enter the title of the organization originating and transmitting the EDT.

- Enter EDT numbers which relate to the data being transmitted.

- Enter the Project/Program/Department/Division title or Project/Program acronym or Project Number, Work Order Number or Organization Code.

- Enter the name of the individual identified as being responsible for coordinating disposition of the EDT.

- Enter related Purchase Order (P.O.) Number, if avsilable.

- Enter special or additional comments concerning transmittal, or "Key" retrioval words may be entered.

- Enter equipment/component number of affected item, if appropriate.

- Enter applicable system, building or facility number, if appropriate.

- Enter spocial or additional comments concerning transmittal.

- Enter applicable drawing number of major ascembly, if appropriate.

- Enter applicable permit or permit application number, if appropriate.

- Enter the date a response is required from individuals identified in Block 17 (Signature/Distribution).

- Enter sequential number, beginning with 1, of the information listed on EDT.

- Enter the unique identification number assigned to the document or drawing being transmitted.

- Enter the sheet number of the information being transmitted. If no sheet number, leave blank.

- Enter the revision number of the information being transmitted. If no revision number, leave blank.

- Enter the title of the document or drawing or a brief description of the subject if no titlo is identified.

- Enter the appropriate Approval Designator (Block 15). Also, indicate the appropriate approvals for each item listed, i.e.. SO. ESO, etc.

- Enter the appropriate code to identify the purpose of the date transmitta! (see Block 16).

- Enter the appropriate disposition code (see Block 16).

- Enter the appropriate disposition code (see Block 16).

- Number codes used in completion of Blocks 15 (G), (H), and (I), and 17 (G), (H) (Signature/Distribution).

- Enter the code of the reason for transmittal (Block 16).

- Enter the code for the disposition (Black 16).

- Enter the signature of the individual completing the Disposition 17 (H) and the Transmittal.

- Obtain appropriate signature(s).

- Enter date signature is obtained.

- Enter MSIN. Note: If Distribution Sheet is used, show entire distribution fincluding that indicated on Page 1 of the EDTI on the Distribution Sheet.

- Enter the signature and date of the individual originating the EDT fentered prior to transmittal to Receiving Organization\}. If the EDT originator is the cognizant engineer, sign both Blocks 17 and 18 .

- Enter the signature and date of the individual identified by the Receiving Organization as authorized to approve disposition of the EDT and acceptance of the data transmitted. as applicable.

- Enter the signature and date of the cognizant manager. (This signature is authorization for release.)

- Enter DOE approval (if required) by signature or control number that tracks the approval to a signature. and indicate DOE action. 


\section{DISCLAIMER}

Portions of this document may be illegible in electronic image products. Images are produced from the best available original document. 


\begin{tabular}{|l|l|c|}
\hline $\begin{array}{l}\text { 2. Title } \\
\text { Passive Versus Active Mitigation Cost Analysis }\end{array}$ & $\begin{array}{l}\text { 3. Number } \\
\text { WHC-SD-W236A-ES-013 }\end{array}$ & \begin{tabular}{c} 
4. Rev No. \\
\hline 5. Key Words
\end{tabular} \\
$\begin{array}{l}\text { High-Leve1 Waste } \\
\text { Low-Level Waste } \\
\text { Mitigation }\end{array}$ & $\begin{array}{l}\text { 6. Author } \\
\text { Name: J. D. Galbraith }\end{array}$ \\
\hline Signature \\
Organization/Charge Code $71220 / C 13763$ \\
\hline
\end{tabular}

7. Abstract

The scope of this task is to assess the impact of mitigation alternatives for Tanks 241-SY-101 and 241-SY-103 on the Project W-236A Multi-Function Waste Tank Facility. This assessment and other related tasks are part of an Action Plan Path Forward (Thomson 1994) prepared by the Tank Waste Remediation System (TWRS) Life Extension and Transition Program.

Task 3.7 of the Action Plan for Project W-236A MWTF analyzed the comparative cost/risk of two hydrogen gas mitigation alternatives (active versus passive) to recommend the most appropriate course of action to resolve the hydrogen gas safety issue. The qualitative success of active mitigation has been demonstrated through Tank 241-SY-101 testing. Passive mitigation has not been demonstrated but will be validated by laboratory test work performed under Task 3.1 of the Action Plan. It is assumed for this assessment that the uncertainties associated with the performance of either alternative is comparable. Determining alternative specific performance measures beyond those noted are not in the scope of this effort.

8. RELEASE STAMP

CFFIOLAL RELEASE

BYW-235A WT

DATE APR 281995

STATION (36)

CLERK 


\section{RELEASE AUTHORIZATION}

Document Number: WHC-SD-W236A-ES-013, Rev. 0

Document Title: Passive Versus Active Mitigation Cost Analysis

Release Date: $\quad$ Apri1 28, 1995

This document was reviewed following the procedures described in WHC-CM-3-4 and is:

APPROVED FOR PUBLIC RELEASE

WHC Information Release Administration Specialist:

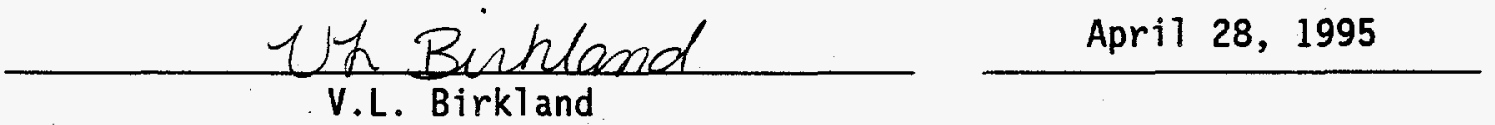

TRADEMARK DISCLAIMER. Reference herein to any specific commercial product, process, or service by trade name, trademark, manufacturer, or otherwise, does not necessarily constitute or imply its endorsement, recommendation, or favoring by the United States Government or any agency thereof or its contractors or subcontractors.

This report has been reproduced from the best available copy. Available in paper copy and microfiche. Printed in the United States of America. Available to the U.S. Department of Energy and its contractors from:

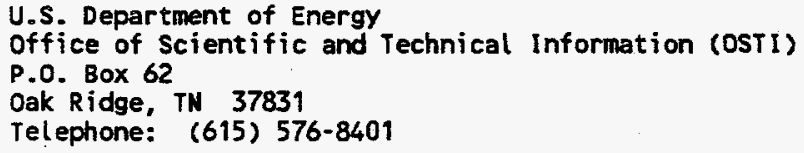

Available to the public from:

U.S. Department of Commerce

National Technical Information Service (NTIS)

5285 Port Royal Road

Springfield, VA 22161

Telephone: (703) 487-4650 
WHC-SD-W236A-ES-013

Revision 0

\title{
PASSIVE VERSUS ACTIVE MITIGATION COST ANALYSIS
}

April 1995

\author{
R. J. Parazin \\ J. D. Galbraith \\ Westinghouse Hanford Company \\ Richland, Washington
}

\section{DISCLAIMER}

This report was prepared as an account of work sponsored by an agency of the United States Government. Neither the United States Government nor any agency thereof, nor any of their employees, makes any warranty, express or implied, or assumes any legal liability or responsibility for the accuracy, completeness, or usefulness of any information, apparatus, product, or process disclosed, or represents that its use would not infringe privately owned rights. Reference herein to any specific commercial product, process, or service by trade name, trademark, manufacturer, or otherwise does not necessarily constitute or imply its endorsement, recommendation, or favoring by the United States Government or any agency thereof. The views and opinions of authors expressed herein do not necessarily state or reflect those of the United States Government or any agency thereof. 
WHC-SD-W236A-ES-013

Revision 0

This page intentionally left blank. 
WHC-SD-W236A-ES-013

Revision 0

CONTENTS

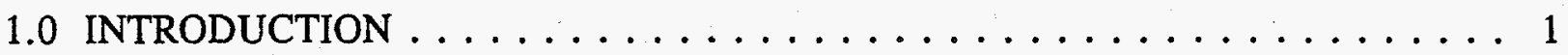

1.1 EXECUTIVE SUMMARY $\ldots \ldots \ldots \ldots \ldots \ldots \ldots \ldots \ldots$

2.0 MITIGATION ALTERNATIVES $\ldots \ldots \ldots \ldots \ldots \ldots \ldots \ldots$

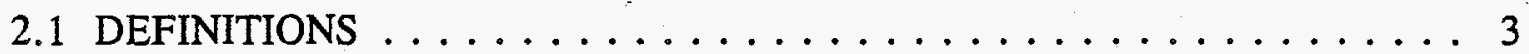

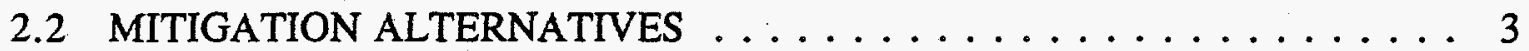

2.2 .1 Active Mitigation Alternative $\ldots \ldots \ldots \ldots \ldots \ldots \ldots$

2.2.2 Passive Mitigation, Alterative $1 \ldots \ldots \ldots \ldots \ldots \ldots$

2.2.3 Passive Mitigation, Alternative $2 \ldots \ldots \ldots \ldots \ldots$

2.2.4 Disposition of Retrieved Waste $\ldots \ldots \ldots \ldots \ldots \ldots \ldots$

3.0 SUMMARY AND CONCLUSIONS $\ldots \ldots \ldots \ldots \ldots \ldots \ldots \ldots \ldots \ldots \ldots$

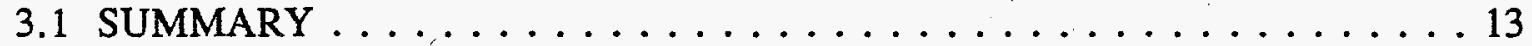

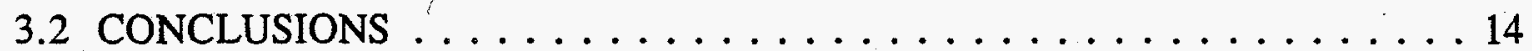

4.0 MITIGATION ALTERNATIVES DESCRIPTIONS AND COSTS $\ldots \ldots \ldots \ldots 15$

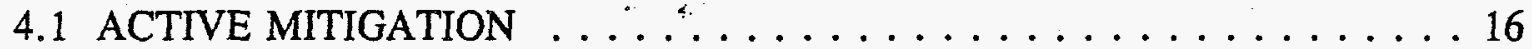

4.1 .1 Assumptions . . . . . . . . . . . . . . . 16

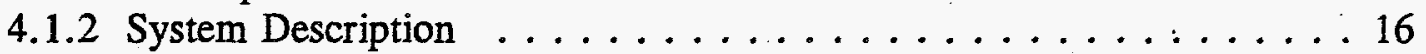

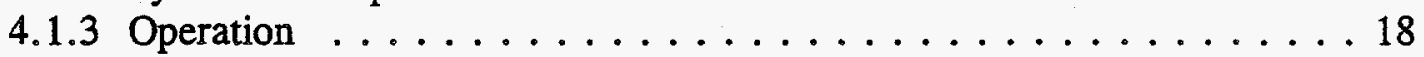

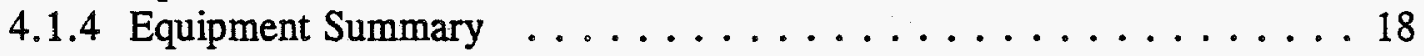

4.1 .5 Cost Estimate for Active Mitigation $\ldots \ldots \ldots \ldots \ldots \ldots \ldots$

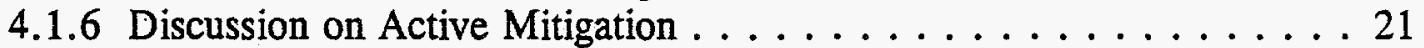

4.2 PASSIVE MITIGATION ALTERNATIVES $\ldots \ldots \ldots \ldots \ldots \ldots \ldots \ldots$

4.2.1 Dilution System Description . . . . . . . . . . . . 22

4.2.2 Jet Mixer Pump and Transfer Pump/Recirculation, Alternative 1 . . . 24

4.2.3 Transfer Pump with Modified Slurry Distributor/Recirculation (Alternative 2) ................... 28

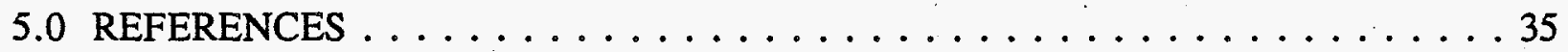

\section{APPENDIX}

A OPERATIONAL COST ASSUMPTIONS $\ldots \ldots \ldots \ldots \ldots \ldots \ldots \ldots$ 
WHC-SD-W236A-ES-013

Revision 0

\section{LIST OF FIGURES}

1. Active Versus Passive Mitigation Block Diagram . . . . . . . . . . . 4

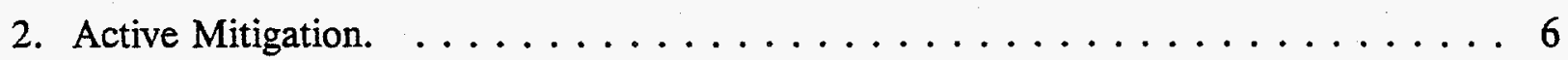

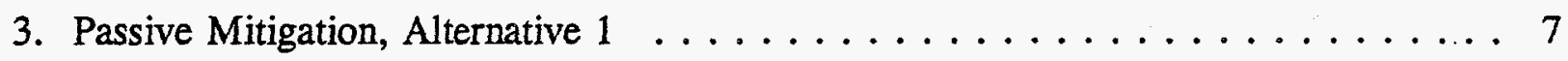

4. Passive Mitigation, Alternative $2 . \ldots \ldots \ldots \ldots \ldots \ldots \ldots \ldots$

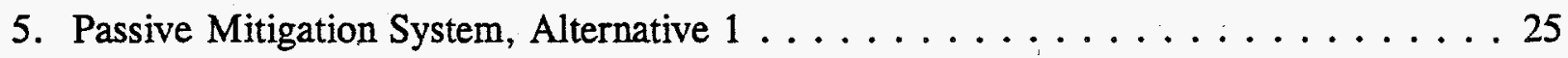

6. Modified Slurry Distributor. . . . . . . . . . . . . . . . . . . 29

\section{LIST OF TABLES}

1. Cost Summary Without Waste Storage Included $\ldots \ldots \ldots \ldots \ldots \ldots \ldots$

2. Summary Cost Comparison Under Conditions A and B . . . . . . . . 14

3. Equipment Summary for Active Mitigation. . . . . . . . . . . . . . . 19

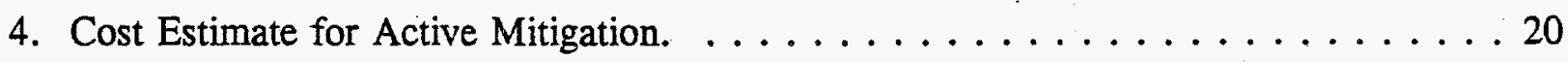

5. Dilution Ratios Versus Volume. . . . . . . . . . . . . 23

6. Cost Estimate for Passive Mitigation, Alternative 1. . . . . . . . . . 27

7. Summary of Life-Cycle Costs for Passive Mitigation, Alternative $1 \ldots \ldots \ldots 28$

8. Life-Cycle Cost for Passive Mitigation, Alternative $2 . \ldots \ldots \ldots \ldots \ldots \ldots \ldots$

9. Summary of Life-Cycle Costs for Passive Mitigation, Alternative $2 \ldots \ldots \ldots 33$ 
WHC-SD-W236A-ES-013

Revision 0

\section{LIST OF TERMS}

DACS

DOE

DST

FTE

GRE

HIC

LFL

LLCE

MWTF

OWVP

PNL

ROM

TWRS

WHC

Digital Acquisition Control System

U.S. Department of Energy

Double-shell tank

Full Time Equivalent

Gas Release Event

High Integrity Container

Lower flammability limit

Long-Length Contaminated Equipment

Multi-Function Waste Tank Facility

Operational Waste Volume Projections

Pacific Northwest Laboratory

Rough order of magnitude

Tank Waste Remediation System

Westinghouse Hanford Company 


\section{WHC-SD-W236A-ES-013}

Revision 0

This page intentionally left blank. 


\author{
WHC-SD-W236A-ES-013 \\ Revision 0 \\ PASSIVE VERSUS ACTIVE \\ MITIGATION \\ COST ANALYSIS
}

\title{
1.0 INTRODUCTION
}

This analysis assesses the impact of mitigation alternatives for Tanks 241-SY-101 and 241-SY-103 on the Project W-236A Multi-Function Waste Tank Facility (MWTF). This assessment and other related tasks are part of an Action Plan Path Forward (Thomson 1994) prepared by the Tank Waste Remediation System (TWRS) Life Extension and Transition Program.

Task 3.7 of the Action Plan for Project W-236A MWTF analyzed the comparative cost/risk of two hydrogen gas mitigation alternatives (active versus passive) to recommend the most appropriate course of action to resolve the hydrogen gas safety issue. The qualitative success of active mitigation has been demonstrated through Tank 241-SY-101 testing. Passive mitigation has not been demonstrated but will be validated by laboratory test work performed under Task 3.1 of the Action Plan. It is assumed for this assessment that the uncertainties associated with the performance of either alternative are comparable. Determining alternative specific performance measures beyond those noted are not in the scope of this effort.

\subsection{EXECUTIVE SUMMARY}

Active mitigation using jet mixer pump systems has successfully demonstrated prevention of episodic gas release events (GREs) with few uncertainties. Due to the cost of required (new) double-shell tank (DST) storage capacity for dilute waste, the two passive mitigation alternatives are significantly more expensive as compared to continuing with active mitigation. If the cost of (new) DST storage capacity is not considered, then Passive Mitigation Alternative 1, using existing jet mixer pump systems with a transfer/dilution system, is comparable to Active Mitigation. Passive Mitigation Alternative 2, using external tank mixing systems (modified slurry distributors), carries a lower cost, but without its demonstration for tank mitigation, carries greater uncertainty. 
WHC-SD-W236A-ES-013

Revision 0

This page intentionally left blank. 
WHC-SD-W236A-ES-013

Revision 0

\subsection{MITIGATION ALTERNATIVES}

This section provides general definitions as well as an introduction to the mitigation alternatives to be assessed including the Tank 241-SY-101 mitigation strategy now in use. Waste storage also is addressed as it relates to specific alternatives. Figure 1 shows a block diagram of the decision logic associated with the mitigation alternatives to be covered.

\subsection{DEFINITIONS}

The following definitions apply throughout this assessment.

Lower Flammability Limit (LFL). The minimum percent concentration of a flammable gas within an air mixture whereby the mixture is considered combustible.

Mitigation. When the flammable gas issue characterized by Tank 241-SY-101 hydrogen releases was initialiy addressed, the method for resolution selected was "mitigation," an approach which minimizes flammable gas concentrations rather than one which deals with flammable concentrations after their generation.

Active Mitigation. Active mitigation achieves the 25 percent LFL condition solely through the periodic, internal mixing of tank waste using a special purpose jet mixer pump. active mitigation must be an ongoing process as long as the potential for episodic releases exists.

Passive Mitigation. Passive mitigation achieves the 25 percent LFL condition solely through in-tank waste dissolution using a balanced $\mathrm{pH}$ solution, which matches the waste $\mathrm{pH}$, that dissolves components of the sludge that retains the gases. Passive mitigation also must include some measure of tank waste mixing, removal, and recirculation. Recirculation may be defined as waste removed from the tank, transferred by pipe routings, and promptly returned to the tank (or simply defined as internal tank mixing or blending). Passive mitigation activities that include any recirculation or mixing are terminated when the prescribed sludge conditions are achieved.

\subsection{MITIGATION ALTERNATIVES}

The method of mitigation selected in February 1992 for Tank 241-SY-101 testing was internal waste tank mixing using a single, centrally-mounted, 150-hp submersible jet mixer pump. The reasons that lead to mitigation by jet mixer pump were based on a number of factors, most notably the availability of an onsite submersible jet mixer pump already procured for the Grout Program. 


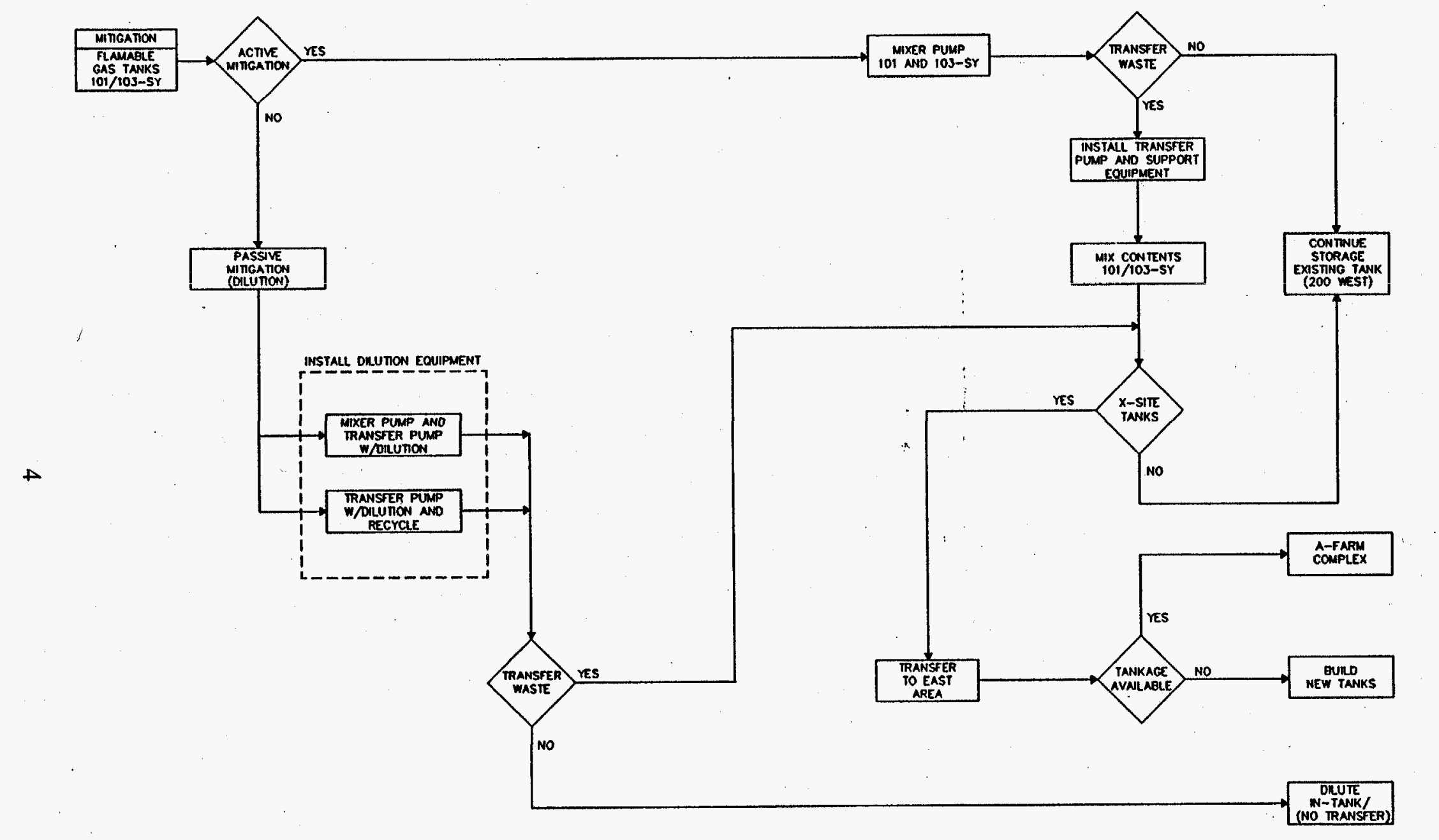

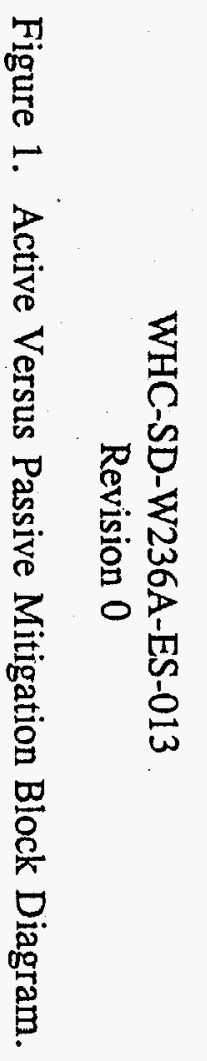

J0G23/CEW/3-14-95-8 
By selecting this option, it was estimated that approximately 1 year could be eliminated from the schedule, minimizing the number of "windows" or episodic GREs. It was recognized that the jet mixer pump being used was not specified for waste in Tank 241-SY-101 and might not work. Accordingly, the following active alternative mitigation options using different methods to mitigate the hazard were selected and funded for parallel development.

- Dilute to reduce percent of solids (function of strength).

- Heat to reduce waste yield stress.

- Use sonic vibration to shear the waste.

The three options were evaluated for feasibility by Pacific Northwest Laboratory (PNL) and the results were published in Assessment of Alternative Mitigation Concepts for Hanford Flammable Gas Tanks, PNL-10105 (Stewart et al. 1994).

\subsubsection{Active Mitigation Alternative}

This alternative is the current baseline strategy used in Tank 241-SY-101. The alternative assumes that the jet mixer pump (and replacements) undergoes periodic operation until waste is removed for treatment, presumably a 10 -year period. Similarly, a jet mixer pump would be installed and operated in Tank 241-SY-103 (see Figure 2).

The operating strategy would be to periodically operate the jet mixer pumps in both tanks for durations and intervals that preclude any episodic flammable GREs. The current operating interval is 3 times per week for a 20 -minute duration. No waste retrieval or dilution is required for active mitigation. The entire operation would extend until waste is removed for treatment.

\subsubsection{Passive Mitigation, Alterative 1}

The scope of Alternative 1 includes the installation of a transfer pump in Tank 241-SY-101 and in-line dilution capabilities. The scope for Tank 241-SY-103 includes the installation of the "new design" jet mixer pump and transfer pump similar to Tank 241-SY-101. Both Tanks 241-SY-101 and 241-SY-103 will be provided with flushing, caustic (and other chemical) addition capabilities and pipe routings from the tank farm (see Figure 3). This system will be connected to the new proposed cross-site transfer system to support future retrieval of the SY tank farm waste.

The operating strategy would be to use the jet mixer pump for a limited period to mix the tank waste and then retrieve a given volume of waste from the tank while adding diluent. Conditioned diluent would be added to the tank to achieve a prescribed dilution ratio, followed by additional tank mixing to accelerate diluent dispersion. The entire operation would take no more than 2 years. 


\section{WHC-SD-W236A-ES-013 \\ Revision 0}

Figure 2. Active Mitigation.

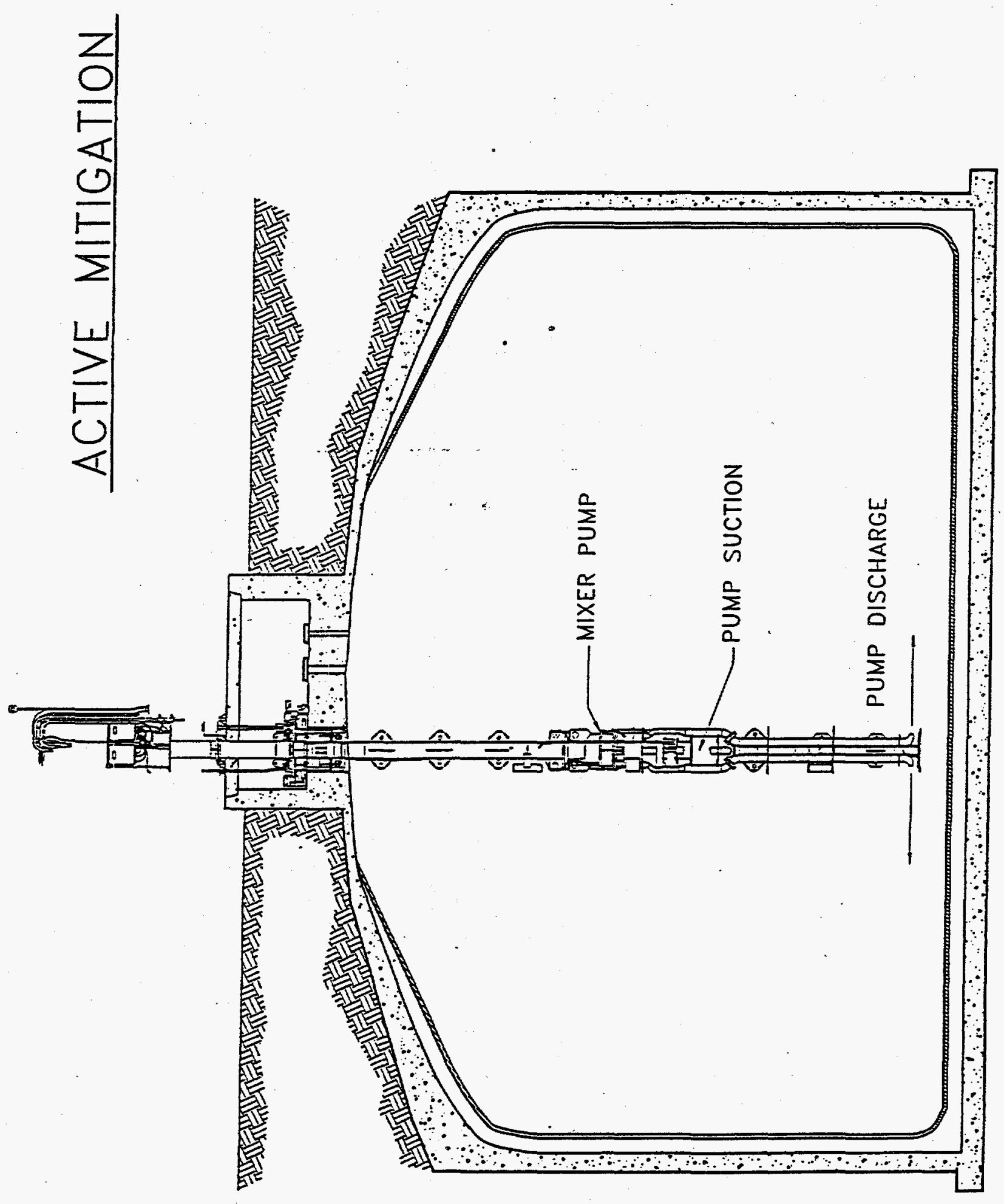

$\frac{1}{1}$
$\frac{1}{3}$
$\frac{1}{2}$
$\frac{1}{5}$

$\leq$ 


\section{WHC-SD-W236A-ES-013 \\ Revision 0}

Figure 3. Passive Mitigation, Alternative 1.
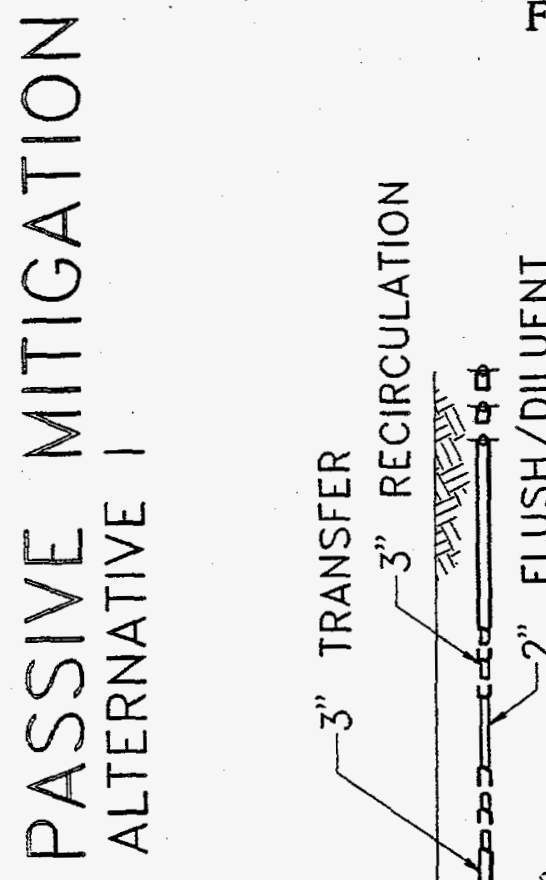

$m$
0
1
$\vdots$
1
$\frac{1}{2}$
1 


\subsubsection{Passive Mitigation, Alternative 2}

Alternative 2 work scope includes using current mixing pump and adding a transfer pump to Tank 241-SY-101 with in-line dilution capabilities. The work scope for Tank 241-SY-103 includes the installation of the transfer pump, but no jet mixer pump installation. Instead of a jet mixer pump, Tank 241-SY-103 will be provided with a pipe routing necessary to recirculate and distribute retrieved and possibly diluted waste back to the tank by an installed modified slurry distributor. The slurry distributor uses similar jet nozzle technology as the jet mixer pump system. A similar slurry distributor installation would be installed in Tank 241-SY-101 if the current mixing pump failed. Tanks 241-SY-101 and 241-SY-103 would be provided with flushing and caustic (and other chemical) addition capabilities in addition to pipe routings from the farm (see Figure 4).

For Tank 241-SY-101, the operating strategy would be to use the current jet mixer pump for a limited period to mix the tank waste and, perhaps, adding diluent before the mixing. The next step would be to retrieve a given amount of mixed waste from the tank. Then, add diluent to the tank to achieve a prescribed dilution ratio, followed by tank mixing for a limited period, and then terminate operations. For Tank 241-SY-103, the operating strategy would be to use the developed pipe routing to recirculate and distribute waste back to the tank through the moveable slurry distributor. Following the recirculation and some dilution, retrieve a prescribed amount of mixed waste and add diluent to the tank to achieve the prescribed dilution ratio in the tank. Follow-on recirculation and mixing of the tanks may also be performed before terminating operations. The entire operation would take no more than 2 years.

\subsubsection{Disposition of Retrieved Waste}

The passive mitigation alternatives produce a volume of diluted mixed waste. For passive mitigation to be successful, acceptable storage capacity for the waste must be available when needed. For this assessment, the alternatives considered for storage are limited to new 200 West Area DSTs and storage existing DSTs in 200 East Area via new or existing cross-site transfer system.

It is assumed that Tank 241-SY-102 cannot be used for waste storage due to waste segregation rules. It is also assumed that Project W-211, Initial Tank Retrieval Systems, will provide the necessary infrastructure to access and use the cross-site system from SY process pits. Task 3.2 of the recommended path forward Action Plan will provide the information necessary to assess the potential impact of retrieved waste added to the DST system between now and 2005. 


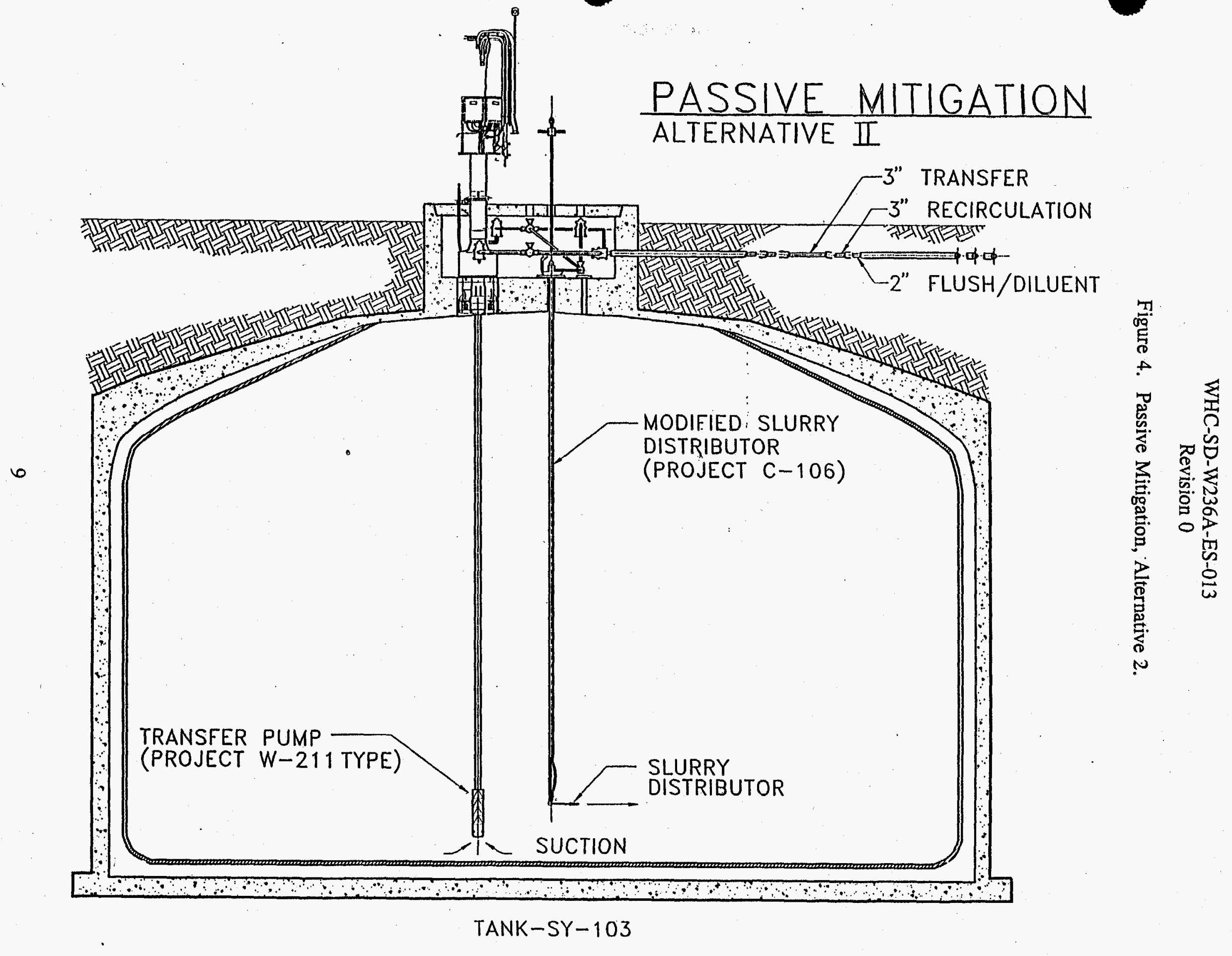




\section{WHC-SD-W236A-ES-013}

Revision 0

This page intentionally left blank. 
WHC-SD-W236A-ES-013

Revision 0

\subsection{SUMMARY AND CONCLUSIONS}

The cost of active mitigation for the noted 10 -year period is $\$ 53$ million. The cost for the two passive mitigation alternatives range from $\$ 56$ million to $\$ 40$ million. Passive Mitigation, Alternative 2, which uses only the addition of transfer pumps to 241-SY-101 and 241-SY-103, appears to be the most cost effective alternative at $\$ 40$ million. Alternative 1 is similar to Alternative 2 but adds a jet mixer pump to Tank 241-SY-103. See the summary cost data in Table 1 for further cost comparisons. If treatment is not available after 10 years, operating costs for Active Mitigation would increase proportionately.

Without consideration of waste storage costs, passive mitigation appears to be more cost effective by approximately $\$ 13$ million. However, this cost advantage may change when waste storage costs are considered.

If the handling and storage of SY retrieved waste in 200 East is viable and cross-site capability is available when necessary, then passive mitigation clearly offers a cost advantage. If it is assumed that the cost of infrastructure needed for passive mitigation, i.e. dilution capabilities, pipe routings, etc., is absorbed by the retrieval mission of Project W-211, the cost advantage (as shown in Table 1) is even larger (see Notes 6 and 7 in Table 1).

The cost advantage of passive mitigation is nullified if storage is unavailable in 200 East. Area and is available only through new tank capacity in 200 West Area. The need for additional capacity in 200 West Area may be driven by other issues, i.e., emergency/contingency storage, waste segregation rules, etc. Under these circumstances, passive mitigation could be considered a potentially cost effective alternative depending on how costs are viewed for new 200 West Area tanks and what other services the tanks would provide. 


\section{Revision 0}

Table 1. Cost Summary Without Waste Storage Included.

\begin{tabular}{|c|c|c|c|}
\hline & $\begin{array}{c}\text { Active } \\
\text { mitigation } \\
\text { (\$ millions) }\end{array}$ & $\begin{array}{c}\text { Passive } \\
\text { mitigation, } \\
\text { Alternative } \\
1^{(6)} \\
\text { (\$ millions) }\end{array}$ & $\begin{array}{c}\text { Passive } \\
\text { mitigation, } \\
\text { Alternative } \\
2^{(7)} \\
\text { (\$ millions) }\end{array}$ \\
\hline \multicolumn{4}{|l|}{ Project } \\
\hline Engineering & $1.5^{1}$ & 8.5 & 8.0 \\
\hline Procure and Fab (1) & $2.0^{1}$ & 13.5 & 12.0 \\
\hline Construction & $1.0^{1}$ & 11.0 & 10.5 \\
\hline DACS Replacement & 8.0 & 8.0 & $\mathrm{~N} / \mathrm{A}$ \\
\hline \multicolumn{4}{|l|}{ Operating costs } \\
\hline Installation in-tank equipment $\cdots$ & $4.0^{5}$ & 4.0 & 2.0 \\
\hline Post installation operational costs & $20.0^{2}$ & $2.0^{4}$ & $2.0^{4}$ \\
\hline Spares & $3.5^{3}$ & N/A & N/A \\
\hline Replacements/Equipment & 7.0 & N/A & $\mathrm{N} / \mathrm{A}$ \\
\hline Disposal of In-Tank Equipment & 1.4 & 1.5 & 2.0 \\
\hline Safety reviews and design reviews & 4.5 & 7.4 & 4.4 \\
\hline Total (rounded to nearest million) & 53.0 & $56.0^{8}$ & $40.0^{(8)}$ \\
\hline
\end{tabular}

${ }^{1}$ Cost is for 241-SY-103 jet mixer pump only. Does not cover expended costs for 241-SY-101.

${ }^{2}$ Assumes operation of both the 241-SY-101 and 241-SY-103 active mitigation systems for 10 years at 11 FTEs per year plus some miscellaneous and essential materials. FTE requirement was provided by tank farm management. Also see appendix A.

${ }^{3}$ Assumes two spares available during the 10 -year operational period.

${ }^{4}$ Assumes 10 FTEs for 1 year plus miscellaneous and essential materials to operate both 241-SY-101 and 241-SY103 passive mitigation systems. This would be to dilute and transfer the required contents to another designated receiver tank.

${ }^{5}$ Assumes three more jet mixer pumps installations over the 10-year operating period

${ }^{6}$ Assumes active mitigation costs plus Project W-211 costs for 241-SY-101 and 241-SY-103. This is a total of \$31 million per revised estimates for 241-SY-101 and conceptual design report costs for 241-SY-103.

${ }^{7}$ Assumes use of Project W-211 system for 241-SY-101 and 241-SY-103 plus installation of "modified slurry distributors."

${ }^{8}$ All passive mitigation system costs do not include costs associated with waste storage, i.e., new tanks, etc.

DACS $=$ Digital Acquisition Control System

FTE = Full Time Equivalent. 
WHC-SD-W236A-ES-013

Revision 0

\subsection{SUMMARY}

As shown in Table 1, passive mitigation represents a cost effective alternative to the current mitigation baseline of jet mixer pumps under either of the following conditions.

A. The existing DST storage system under credible TWRS operating scenarios, has the capability to cross-site transfer, receive, and store $5,340 \mathrm{~m}^{3}(1,410 \mathrm{Kgal})$ of diluted waste from the SY Farm during the 1996 to 1998 time.

B. New DST storage capacity is provided in 200 West Area whereby the incremental cost increase to provide the added tank capacity to accept $5,340 \mathrm{~m}^{3}$ $(1,410 \mathrm{Kgal})$ of dilute $S Y$ farm waste is offset by the savings in implementing passive mitigation; i.e. approximately $\$ 13$ million.

Condition A. Condition A is sensitive to several issues. Needed storage capacity is largely driven by the waste transfer dilution ratio of 1:1 (Hudson et al. 1995) and the in situ waste dilution ratio of 1:1 derived from Task 3.1 of the Action Plan. This is thought to be the best information available through PNL work on waste samples (Stewart et al. 1994). If subsequent analyses or operating conditions result in the need for higher dilution ratios and resulting waste volume increases, the likelihood of finding storage becomes more difficult.

Waste storage capacity in 200 East Area is driven by the evaporator campaigns and tank usage postulated in Task 3.2. The current operational waste volume projections (OWVP) do not include any contingency for receiving a waste stream due to passive mitigation. Therefore, within the current TWRS planning basis, there appears to be little possibility that 200 East Area storage will be available. Thus, Condition A cannot be met under the present baseline.

Condition A also may be placed in jeopardy if the cross-site transfer system is unavailable during calendar years 1996 to 1998 , the time when passive mitigation could logically be implemented.

Condition B. Sensitivities to other 200 West Area storage needs could jeopardize Condition B if additional tank capacity is provided but committed to other uses, i.e. retrieval, waste staging, etc. Condition $B$ is similarly sensitive to the dilution ratio.

If the new 200 West Area tank capacity is primarily driven by a passive strategy, but other drivers exist (but do not mandate additional tanks), the interpretation in liquidating tank cost to mitigation would become critical to satisfying Condition B's cost/benefit basis. Currently, the "cost" of the new storage tanks in 200 West Area for mitigation is considered $\$ 32$ million (prorated cost for 10 years of the 50-year design life) for this assessment. This cost has discounted escalation and contingency. This $\$ 32$ million estimate does not offset the expected savings in implementing passive mitigation. 


\section{WHC-SD-W236A-ES-013 \\ Revision 0}

Table 2 develops summary cost comparisons of active versus passive mitigation under Conditions $\mathrm{A}$ and $\mathrm{B}$. The table shows that active mitigation becomes more cost effective if new tanks are required in 200 West Area; $\$ 53$ million for active versus $\$ 72$ million for Passive Mitigation, Alternative 2. It also shows that with storage available in 200 East, passive mitigation is more cost effective.

Table 2. Summary Cost Comparison Under Conditions A and B.

\begin{tabular}{|l|c|c|}
\hline \multirow{2}{*}{ Mitigation alternative } & \multicolumn{2}{|c|}{ Cost (\$ millions) } \\
\cline { 2 - 3 } & $\begin{array}{c}\text { Condition A } \\
\text { (with storage at 200 } \\
\text { East Area) }\end{array}$ & $\begin{array}{c}\text { Condition B } \\
\text { (with new tanks at } \\
\text { 200 West Area) }\end{array}$ \\
\hline Active & 53 & 53 \\
\hline Passive Mitigation, Alternative 1 & 56 & 88 \\
\hline Passive Mitigation, Alternative 2 & 40 & 72 \\
\hline
\end{tabular}

\subsection{CONCLUSIONS}

Active mitigation appears to remain the preferred method of preventing episodic GREs; it has been demonstrated quite successfully with few uncertainties. Due to the cost of required (new) DST storage capacity for dilute waste under Condition B, the two passive mitigation alternatives are significantly more expensive when compared to Active Mitigation, (see Table 2). If the cost of (new) DST storage capacity is not considered (Condition A), then Passive Mitigation Alternative 1 using existing jet mixer pump systems with a transfer/dilution system is comparable to active mitigation. Passive Mitigation Alternative 2 using external tank mixing systems (modified slurry distributors) carries a lower cost, but without its demonstration for tank mitigation, carries greater uncertainty. 
WHC-SD-W236A-ES-013

Revision 0

\subsection{MITIGATION ALTERNATIVES DESCRIPTIONS AND COSTS}

This section provides the assumptions, detailed descriptions, and costs associated with each mitigation alternative. As identified in Section 1.0, Task 3.7 is being performed in parallel with other Action Plan tasks to support the MWTF Position Paper. Other key tasks and their relationship to hydrogen mitigation are as follows.

Task 3.1, Tanks 241-SY-101 and 103 Dilution Ratios. Dilution ratios are the key factors in determining the amount of storage capacity required in implementing passive mitigation. This task is to develop the technical basis and selection of the dilution ratios that strike the proper balance between introducing an adequate passive mitigation technique and to facilitate the transfer of diluted waste. Preliminary information from this effort suggests an in-tank waste dilution ratio of 1:1 and a similar dilute waste transfer ratio of 1:1. Preliminary work performed by PNL (Stewart et al. 1994) has preceded this task to address the dilution issue.

Task 3.2, Evaporator System Performance. Available DST storage capacity is critical to the viability of passive mitigation. This task will determine the amount of waste volume reduction that is obtainable by the evaporator system resulting in obtaining more realistic conclusions regarding the need or availability of additional DST storage space. Preliminary work performed under this task and the current waste volume projection indicates that, with the present DST system, there will be no planned storage capacity available when needed for a passive mitigation strategy.

The following are general assumptions used in development of this section. Assumptions specific to an alternative will be identified under their respective sub-section.

Safety Analysis. It is assumed from a waste tank safety standpoint that all mitigation alternatives are comparable. In reality a safety analysis of the alternatives would indicate differences in risks and hazards between alternatives, but it is believed that through the use of proper design and operational controls, the risk of ignition-related accidents could be reduced to an acceptable level. Passively preventing a GRE may arguably carry less risk than actively mitigating a GRE, but the pursuit of this issue is beyond the scope of this effort. However, funding of a safety analysis is included in the cost estimates.

Sunk Costs. For cost estimates developed under Task 3.7, it is assumed that past sunk costs related to equipment development and fabrication of "first-of-kind" systems, i.e., Digital Acquisition Control System (DACS), the original SY jet mixer pump, etc., will not be carried forward and included in estimates of these systems. Previous sunk costs were driven artificially high due to limited schedule constraints associated with meeting "windows" between episodic GREs and other drivers. 
WHC-SD-W236A-ES-013

Revision 0

Project Costs. Where project cost estimates were available for specific systems and equipment used in a given alternative, they are used as baseline estimates and

appropriately referenced. Related projects included Projects W-151, W-211, W-236a, W-320, and the Waste Tank Safety Program.

Installed Equipment/Systems. When an alternative utilizes existing equipment and systems, only the cost burden of removal and disposal packaging will be included in the alternative estimate. Costs of spare and replacement equipment will be included.

Duration. It is assumed the need for mitigation of Tanks 241-SY-101 and -103 extends for 10 years.

\subsection{ACTIVE MITIGATION}

This section describes the active mitigation strategy using jet mixer pumps installed in Tanks 241-SY-101 and 103. Using the present jet mixer pump for mitigation purposes was adequate in 1993. Continued use of the jet mixer pumps for active mitigation of the remaining watch-list tanks is the expected baseline alternative of the Waste Tank Safety Program.

Mitigation performance data can be found in Mitigation of Tank 241-SY-101 by Pump Mixing: Results of Testing Phase $A$ and B, PNL-9423 (Allemann et al. 1994), which documents the findings of on-going tests.

\subsubsection{Assumptions}

Spare Equipment. For cost purposes it is assumed that each jet mixer pump will be replaced during the mitigation period and that costs will include a replacement pump, handling, and disposal of all pumps used. Costs for two spare jet mixer pumps will be included in the alternative estimate. The need for spares is driven by a Safety Assessment (LANL 1994) requirement.

\subsubsection{System Description}

Each tank will be provided with a jet mixer pump and the necessary infrastructure for operation, monitoring, and control. Tank 241-SY-101 would use the mixer and infrastructure currently in place. A new mixer would be designed for Tank 241-SY-103. The final design report for the current mixer pump, Final Design Report for Mitigation Mixing Test of Hanford Site Hydrogen Gas-Generating Waste Tank SY 101, WHC-SD-WM-ER-158 (Benegas 1992), provides a detailed description of the pump in tank 241-SY-101. The functional design criteria document for the spare mitigation jet mixer pump, Spare Mitigation/ Retrieval Mixer Pump, WHC-SD-WM-FDC-036 (Benegas 1995) 
provides the detailed requirements for the pump that would be installed in Tank 241-SY-103.

A central pump pit with a $1.07-\mathrm{m}$ (42-in.) riser will be used for the installation of the mixer in each tank. The pit cover blocks must be modified to accommodate the mixer installation. Each pit is equipped with a load distribution frame designed to support all loading experienced by the mixer pump's structure. The load distribution frame also serves as a base for the decontamination spray ring and the riser-to-pump transition piece. The frame is constructed to carry all the downward and side loading placed on the pump. The load frame transfers vertical loading of the pump to the pump pit floor.

An impact limiter is provided in each pit to mitigate damage to the waste tank if the pump is dropped during installation or removal. The impact limiter consists of two honeycomb impact limiter structures.

Electrical power is supplied to both mixer pump assemblies through surface run conduits. The conduits also carry various instrument leads from the motor, pump, and discharge piping locations, through the dome, and out the pump pit to the control system trailer. A single control systems trailer will service both tank operations. A DACS sited in the trailer will control the mixer pumps operations, ancillary systems, and equipment. The DACS consists primarily of a computer-baséd system, including central processing units, monitors, user keyboards, and data storage devices, as well as other peripherals to complete the system. The DACS is capable of both real time display and data acquisition, archiving, and backup.

The DACS provides appropriate alarms and initiates corrective actions required to maintain the tank testing systems in a safe mode of operation. If conditions deteriorate, the DACS also will safely shut down equipment to prevent equipment damage. The operator will be able to interface with the various monitoring and auxiliary systems through operator stations or by controls located on a control panel, both of which will be located in a control area in a utility trailer near the tank site

Instrumentation for monitoring tank behavior during the mixer pump operations will be provided at various locations throughout the tank. The waste level measurement and hydrogen concentrations within the tank and vent header are of primary importance. In addition, the remaining instrumentation provides information that will be used to control the test, provide abort capabilities, and protect equipment.

Each tank contains a total of three $1.07-\mathrm{m}$ (42-in.) risers. The mixer pump will be installed in the central riser (riser 12A) located in the central pump pit. Risers 5A and 5B will contain a TV camera and light assemblies. One riser on each tank is equipped with an MPR assembly for over pressure relief. 
WHC-SD-W236A-ES-013

Revision 0

\subsubsection{Operation}

The mitigation operating strategy would call for the periodic operation of mixer pumps in both tanks for durations and intervals that preclude any episodic flammable GRE. Mitigation performance data are found in Mitigation of Tank 241-SY-101 by Pump Mixing: Results of Testing Phase $A$ and B, PNL-9423 (Allemann et al. 1994), which documents the findings of on-going tests starting in July 1993. Through continued testing and evaluation of the mixer system capabilities and limitations, the mitigation program has settled on an mixer operating interval of 20 minutes three times per week for 241-SY-101. It would be presumed that a similar operating sequence would be instituted for 241-SY-103. However, it is likely that there will be sufficient differences between the tanks, mixer systems, etc., that the operating durations and frequencies will vary.

It is assumed that an additional 11 FTEs would be needed to support the mitigation operation. Personnel would be supplemented as required to support equipment decontamination, replacement; and other major activities. Because active mitigation involves no waste transfer, there is little operational interfacing with waste transfer. All routine surveillance of the tanks would be performed through mitigation activities.

\subsubsection{Equipment Summary}

Table 3 identifies the major equipment, facilities, and facility modifications needed for active mitigation.

\subsubsection{Cost Estimate for Active Mitigation}

Costs for the addition of a jet mixer pump to tank 241-SY-103 were obtained from the Tank Waste Safety Program Office. These costs are represented as "Project" in Table 4. Operating costs were formulated based on discussion with the Tank Waste Safety Program office and operational personnel. Relevant assumptions are presented as footnotes to the table. 
WHC-SD-W236A-ES-013

Revision 0

Table 3. Equipment Summary for Active Mitigation.

\begin{tabular}{|l|l|l|}
\hline \multicolumn{1}{|c|}{ Item } & \multicolumn{1}{|c|}{ 241-SY-101 } & \multicolumn{1}{c|}{ 241-SY-103 } \\
\hline Jet Mixer Pump & $\begin{array}{l}\text { Existing Barrett Haentjens, } \\
\text { 150-hp, modified from grout } \\
\text { mixer for NEC-hazardous } \\
\text { service }\end{array}$ & $\begin{array}{l}\text { New jet mixer pump, to } \\
\text { comply with } \\
\text { WHC-SD-WM-FDC-036 }\end{array}$ \\
\hline $\begin{array}{l}\text { Central Pump Pit and Cover } \\
\text { Block Modifications }\end{array}$ & Existing & $\begin{array}{l}\text { Modified similar to } \\
\text { 241-SY-101 to } \\
\text { accommodate new pump } \\
\text { configuration. }\end{array}$ \\
\hline DACS and Control Trailer & $\begin{array}{l}\text { Modified to accommodate } \\
\text { parallel tank operations }\end{array}$ & N/A \\
\hline Electrical for Mixer & Existing & New \\
\hline $\begin{array}{l}\text { Instrumentation for Mixer } \\
\text { Ops }\end{array}$ & Existing & New \\
\hline HVAC Upgrades & Existing & $\begin{array}{l}\text { Moderate instrumentation } \\
\text { upgrades }\end{array}$ \\
\hline
\end{tabular}


WHC-SD-W236A-ES-013

Revision 0

Table 4. Cost Estimate for Active Mitigation.

\begin{tabular}{|c|c|}
\hline & $\begin{array}{c}\text { Jet mixer pump system } \\
(\$ \text { millions })\end{array}$ \\
\hline \multicolumn{2}{|l|}{ Project $^{1}$} \\
\hline Engineering & 1.5 \\
\hline Procurement and Fabrication & 2.0 \\
\hline DACS Replacement & 8.0 \\
\hline Construction & 1.0 \\
\hline \multicolumn{2}{|l|}{ Operating Costs } \\
\hline Installation and removal of in-tank equipment & $4.0^{2}$ \\
\hline Post Installation Costs & $20.0^{3}$ \\
\hline Spares & $3.5^{4}$ \\
\hline Replacements/Equipment & $7.0^{5}$ \\
\hline Disposal of In-Tank Equipment & $1.4^{6}$ \\
\hline Safety Reviews and Design Reviews & $4.5^{7}$ \\
\hline Total (rounded to the nearest million) & 53.0 \\
\hline
\end{tabular}

'Procurement and fabrication costs are for obtaining in-tank equipment. The "DACS Replacement" is assumed to be an upgraded control trailer that would support the parallel operation of tanks 241-sY-101 and -103.

"Construction" costs cover modifications to the central pump pit for installation of the jet mixer pump, electrical upgrades, instrument systems, etc.

${ }^{2}$ Assumes three jet mixer pumps will be installed over the course of 10 years, and four will be removed for disposal. Each removal and installation is estimated to cost $\$ 1$ million. The average life of a jet mixer pump is assumed to be 8 years.

${ }^{3}$ Assumes 11 FTEs per year will be required over the 10-year operating period to operate and maintain the active mitigation system. The average cost of one FTE is $\$ 150,000 /$ year. Included are approximately $\$ 300,000 /$ year miscellaneous and essential materials costs.

${ }^{4}$ Covers the cost for one spare jet mixer pump.

${ }^{s}$ Covers the cost of two replacement jet mixer pumps over the operating period.

${ }^{6}$ Covers the cost of four disposal containers for failed jet mixer pumps. It is assumed that 4 pumps will fail and have to be disposed of over the 10-year operational period. Cost includes operations support for the removal, field packaging, and delivery to solid waste disposal (see Appendix A, Disposal Cost Assumptions).

${ }^{7}$ Covers the cost for safety and design reviews for the operational period. 
WHC-SD-W236A-ES-013

Revision 0

\subsubsection{Discussion on Active Mitigation}

Active mitigation via jet mixer pumps is proven technology. No further testing is necessary to ensure satisfactory performance in another DST with comparable waste inventory. However, the use of jet mixer pumps for mitigation, though successful, is costly, not only in equipment and infrastructure, but also in operational costs. From an operational standpoint it does not involve the movement of any waste materials nor place a particularly large burden on TWRS operational support resources beyond those identified. It requires little integration with other operations and is largely limited to the tanks involved. It can be viewed as a "standalone" operation. The shortcoming of active mitigation is that it is an active, dynamic, and continuous process that does nothing to eliminate the underlying mechanisms/conditions that initially create the hazardous GREs.

In summary, active mitigation remains a satisfactory, somewhat costly method of managing GREs. It does not eliminate any of the underlying causes. However, it has been thoroughly tested and carries sufficient empirically derived performance data to assure that its application to other tanks with similar GRE potential would be satisfactory.

\subsection{PASSIVE MITIGATION ALTERNATIVES}

Passive mitigation eliminates the GRE by diluting the tank waste to a level that eliminates the gas retention characteristic of the waste. It is stated in (Stewart et al. 1994) that "the sludge will retain gas if the solid-liquid matrix has at least sufficient strength to prevent bubbles from rising through it." For dilution to be successful, diluent will have to be thoroughly mixed with the sludge to eliminate the solid-liquid matrix in the tank. To accomplish this goal, it was concluded that a dilution/mixing system would be used. This system would provide adequate support of tank waste dilution for mitigation, retrieval, and waste transfer operations.

The configuration of the dilution system would use either existing designed jet mixer pumps (Alternative 1) or a modified slurry distributor (Alternative 2) system for initial mobilization of sludges. Once the initial mobilization has been achieved, the installed dilution system would be started, functioning initially in a recirculation operation mode. The transfer pump system would be equipped with in-line caustic mixing to the diluent injection and will mix the solids and diluent.

The tank contents are first mixed to achieve homogeneity. To provide tank space for dilution a prescribed amount of waste is then transferred from the tank, appropriately diluted and moved to another tank for storage. Diluent is then added to the prescribed in-tank dilution ratio. Following the diluent addition the tank is again mixed to disperse the diluent and achieve waste homogeneity. Variations in this strategy may occur to better optimize the dilution process. For example, diluent may be added to the tank before initial mixing, if space is available, to accelerate initial mixing. Initial mixing may be integrated with waste dilution for a similar reason. A definitive strategy on passive mitigation would be developed 
based on findings derived from ongoing laboratory work by PNL Task 3.1 of the Action Plan.

\subsubsection{Dilution System Description}

The purpose of the dilution system is to add chemically treated water to the tank waste or the waste being removed from the tank.

The dilution system concept would include hot water and caustic solution supply, isolation tank for mixing water and caustic solution, and a transfer pump. The transfer pump would introduce diluent at the pump suction. Instrumentation would be provided at the transfer pump to determine the waste properties such as density, viscosity, flow, temperature, and pressure. The following modes of operation would be provided with the transfer system.

Recirculation. Transfer pump circulates waste back into the tank while diluent is added at the pump suction until correct waste properties are achieved for transfer and/or tank space will allow no further addition of diluent. On-line instrumentation will be monitored during this phase of operation.

Transfer. Diluted waste is routed into the cross-site transfer system and transferred to another DST, either in 200 East Area or the new 200 West Area DSTs.

Bypass. When on-line instrumentation detects that waste being transferred is out of specification, the flow is diverted from the transfer line to the recirculation loop and back into the tank. Bypass operations will continue until the waste achieves the required specification, via addition of diluent or continued conditioning/mixing.

Flush. The transfer lines are preconditioned with diluent prior to starting a transfer, and to continue a transfer after bypass. The transfer lines also are flushed after completing a transfer operation before shutdown.

Passive mitigation alternatives will be evaluated using both $.5: 1$ and $1: 1$ dilution ratios (concluded in An Assessment of the Dilution Required to Mitigate Hanford Tank 24I-SY-10I [Hudson et al. 1995]). The dilution system would use a $2 \mathrm{M}$ free (OH-) diluent. By using the dilution ratios recommended it will be necessary to transfer a portion of the tank waste to another DST. This could be accomplished by transferring the waste to existing 200 East Area DSTs or to the new MWTF 200 West Area tanks. Table 5 identifies the tank space required to support the two dilution ratios. 
WHC-SD-W236A-ES-013

Revision 0

Table 5. Dilution Ratios Versus Volume.

\begin{tabular}{|c|c|c|c|c|}
\hline Tank & $\begin{array}{l}\text { In-tank dilution } \\
\text { ratio }\end{array}$ & $\begin{array}{c}\text { Tank waste } \\
\text { removed } \\
(\mathrm{Kgal})\end{array}$ & Waste transfer ratio & $\begin{array}{c}\text { Storage } \\
\text { volume req } \\
(\mathrm{Kgal})\end{array}$ \\
\hline \multirow{4}{*}{ 241-SY-101 } & \multirow{2}{*}{$.5: 1$} & \multirow{2}{*}{337} & $1: 1$ & 674 \\
\hline & & & $3: 1$ & 1348 \\
\hline & \multirow{2}{*}{$1: 1$} & \multirow{2}{*}{527} & $1: 1$ & 1054 \\
\hline & & & $3: 1$ & 2108 \\
\hline \multirow{4}{*}{ 241-SY-103 } & \multirow{2}{*}{$.5: 1$} & \multirow{2}{*}{12} & $1: 1$ & 24 \\
\hline & & & $3: 1$ & 48 \\
\hline & \multirow{2}{*}{$\begin{array}{l}1: 1 \\
\cdots: 1\end{array}$} & \multirow{2}{*}{178} & $1: 1$ & 356 \\
\hline & & & $3: 1$ & 712 \\
\hline
\end{tabular}

The primary uncertainty associated with the passive mitigation alternatives is the dilution ratio necessary to mitigate the gas retention properties of the sludge/tank waste. This issue is being addressed by MWTF Path Forward Task 3.1/Optimum Dilution Ratios, as noted in Section 4.0.

4.2.1.1 General Assumptions. The following assumptions apply to the passive mitigation alternatives:

- Either a waiver will be provided for using the existing cross-site transfer system or Project W-058/W-028 will be completed.

- Dilution of the tank waste will resolve the solid-liquid matrix that will eliminate the gas retention characteristics. The gas release rate will not exceed filling the tank vapor space with hydrogen or flammable gases above the 25 percent of the LFL.

- Passive mitigation is achieved within one to two years of operation of the installed equipment. 


\subsubsection{Jet Mixer Pump and Transfer Pump/Recirculation, Alternative 1}

The jet mixer pump and the transfer pump system will use the equipment and facility modifications that have currently been made and are planned to be made to the SY tank farm.

Implementation of this alternative uses the currently installed tank waste safety mixer for tank 241-SY-101 and assumes that the 241-SY-103 would be equipped with a new generation jet mixer, currently planned by Tank Waste Safety Program and modifications provided by Project W-211. The modifications to the 241-SY-103 tank will include modifications to the central pump pit for the load distribution frame and electrical upgrades. The cover blocks will be modified as required to support the new equipment. Project W-211 modifications include the following:

- Modify existing valve pits to house a transfer booster pump and flush pump.

- Install new jumpers as required to support the operation of the transfer pump, dilution system and flush system.

- Install a flush tank, chemical unloading pad, and an instrument control building to support the operation of transfer, dilution, and flush systems.

- Install video monitoring systems.

- Operator station includes monitor, alarm, and control retrieval systems for each tank as well as interface with the cross-site transfer system provided by Project W-058.

Figure 5 provides a general concept of the passive mitigation system.

The system will interface with existing instrumentation critical to the mixing or transfer process to monitor tank waste, shell, and air space temperatures, and waste levels within the tank.

4.2.2.1 Operations Description. Passive mitigation Alternative 1 would operate as follows. The tank contents are mobilized via operation of the jet mixer pump to achieve a measure of waste homogeneity. To provide tank space for dilution, a prescribed amount of waste is then transferred via the transfer pump/dilution system. The waste being transferred is diluted to meet a specified waste concentration that complies with transfer system requirements and is then moved to another tank for storage. Via the dilutions system, diluent is then added to the tank to reach the prescribed waste dilution ratio. Following the diluent addition to the tank, the jet mixer pumps are again operated to disperse the diluent and achieve waste homogeneity. 
$W^{H} C-S D-W 236 A-E S-013$

Rev 0

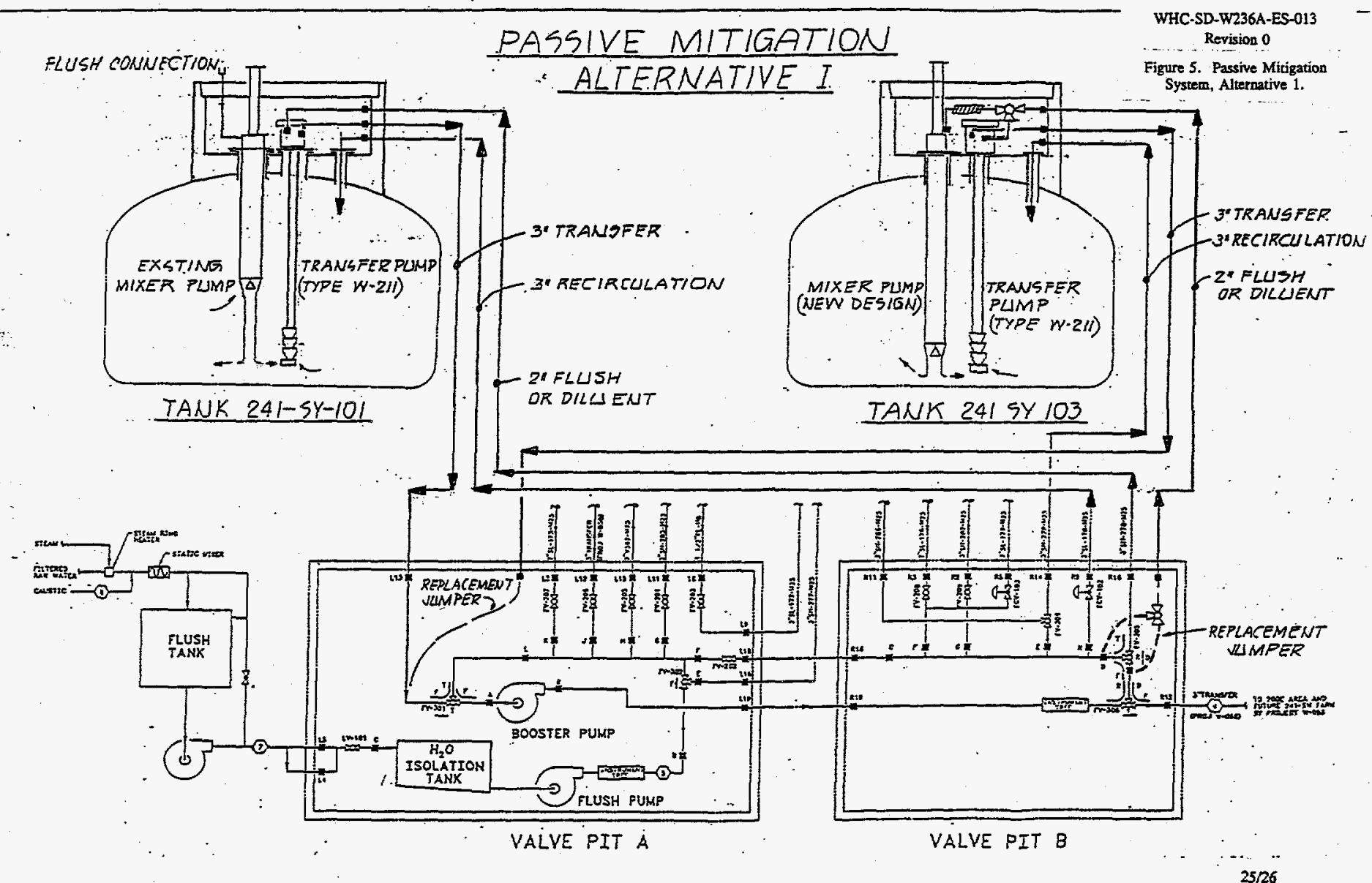


4.2.2.2 Cost Estimate. Table 6 provides a rough order of magnitude (ROM) cost breakdown for Passive Mitigation, Alternative 1. Table 7 summarizes the costs for the systems being provided to derive a total life-cycle cost. Cost data used to assemble the ROM cost estimates are identified in the notes for Table 6.

Table 6. Cost Estimate for Passive Mitigation, Alternative 1.

\begin{tabular}{|c|c|c|c|}
\hline & \multirow{2}{*}{$\begin{array}{l}\text { Jet mixer pump system } \\
\text { ( } \$ \text { millions) }\end{array}$} & \multicolumn{2}{|c|}{ Dilution system ( $\$$ millions) } \\
\hline & & $241-S Y-101^{(3)}$ & $241-S Y-103^{(4)}$ \\
\hline \multicolumn{4}{|l|}{ Project } \\
\hline Engineering & $1.5^{(1)}$ & 5.3 & 1.7 \\
\hline Procurement and Fabrication & $2.0^{(1)}$ & 9.9 & 1.6 \\
\hline DACS Replacement & $8.0^{(1)}$ & $\mathrm{n} / \mathrm{a}$ & $\mathrm{n} / \mathrm{a}$ \\
\hline Construction & $1.0^{(1)}$ & 6.9 & 3.1 \\
\hline \multicolumn{4}{|l|}{ Operating Costs } \\
\hline Install in-tank equipment & $\therefore \quad 2.0^{(1)}$ & $1.0^{(5)}$ & $1.0^{(5)}$ \\
\hline Post Installation Costs & & $2.0^{(6)}$ & \\
\hline Spares & $\mathrm{n} / \mathrm{a}$ & $\mathrm{n} / \mathrm{a}$ & $\mathrm{n} / \mathrm{a}$ \\
\hline Replacements/Equipment & $\mathrm{n} / \mathrm{a}$ & $\mathrm{n} / \mathrm{a}$ & $\mathrm{n} / \mathrm{a}$ \\
\hline $\begin{array}{l}\text { Disposal of In-Tank } \\
\text { Equipment }\end{array}$ & $0.7^{(2)}$ & $0.4^{(2)}$ & $0.4^{(2)}$ \\
\hline $\begin{array}{l}\text { Safety Reviews and Design } \\
\text { Reviews }\end{array}$ & 4.5 & 2.3 & 0.6 \\
\hline $\begin{array}{l}\text { Total (rounded to the nearest } \\
\text { million) }\end{array}$ & 20.0 & 28.0 & 8.0 \\
\hline
\end{tabular}

${ }^{1}$ Costs are taken from the active mitigation costs to cover the installation of a jet mixer in the tank 241-SY-103. The tank 241-SY-101 mixer is assumed to be operational and, therefore, the cost is not included.

${ }^{2}$ Cost covers two disposal containers for removal of jet mixer pumps and two transfer pumps after mitigation activities are completed. Cost includes operations support for the removal, field packaging, and delivery to solid waste disposal (see Appendix A, Disposal Cost Assumptions).

${ }^{3}$ Project costs for the taniss 241-SY-101 transfer system as scoped by Project W-211. Cost associated with the safety reviews and design reviews are tabulated at the end of the table.

${ }^{4}$ Project costs for tank 241-SY-103 transfer system upgrades to tank 241-SY-101 system.

${ }^{5}$ Cost for installation of transfer pumps and jumpers.

${ }^{6}$ Cost covers average of 10 FTEs for one year and miscellaneous cost of $\$ 500,000$. One FTE is $\$ 150,000 /$ year. 
WHC-SD-W236A-ES-013

Revision 0

Table 7. Summary of Life-Cycle Costs for Passive

Mitigation, Alternative 1.

\begin{tabular}{|l|c|}
\hline \multicolumn{1}{|c|}{ System } & $\begin{array}{c}\text { Life-cycle cost } \\
\text { (\$ millions) }\end{array}$ \\
\hline 241-SY-101 dilution system & 28 \\
\hline 241-SY-103 dilution system & 8 \\
\hline Jet mixer pump system & 20 \\
\hline Total & 56 \\
\hline
\end{tabular}

4.2.2.3 Discussion. Passive mitigation using jet mixer pumps with waste transfer pumps combines the success of the mixer technology in both mobilizing and mixing tank waste layers with the dilution concept of mitigation to achieve an in-tank waste state that cannot generate any GREs. The alternative carries the cost burden of installing and operating mixer pumps for a limited period and the transfer pumps used to remove waste from the tanks following mixing. A dilution and diluent preparation/feed system is also required: One primary benefit of Passive Mitigation, Alternative 1, is that the technology is familiar in both the jet mixer and transfer pumps. However, there are little operational data on the diluent mixing performance as used in this application. Another shortcoming is that dilution has not been operationally demonstrated as a successful mitigation mechanism and the degree of mixing required following dilution has not be quantified. Only currently developed laboratory data would provide the technical basis for implementing this alternative.

Alternative 1 implements familiar and relatively expensive technology for a limited period to eliminate the potential for GREs with success closely tied to the validity of laboratory data developed on dilution and waste mixing.

\subsubsection{Transfer Pump with Modified Slurry Distributor/Recirculation (Alternative 2)}

Alternative 2 is similar to Alternative 1 with the exception that the jet mixer pumps would be replaced with a modified slurry distributor. The modified slurry distributor will be similar to the sluicer being designed for Project W-320, 241-C-106 Waste Retrieval. The system provided by Project W-211 will be modified as required to support achieving required slurry velocities and pressure requirements. Alternative 2 is illustrated by Figure 6.

The modified slurry distributor will be installed to an elevation in the tank to maximize the conditioning/mixing of the nonconvective layer of the tank. The equipment will have a designed capability to be rotated on its vertical axes and have 10 to 20 degree motion in the horizontal axes. These features will allow the slurry distributor to sweep the tank for the entire nonconvective layer, therein mobilizing the solids. 


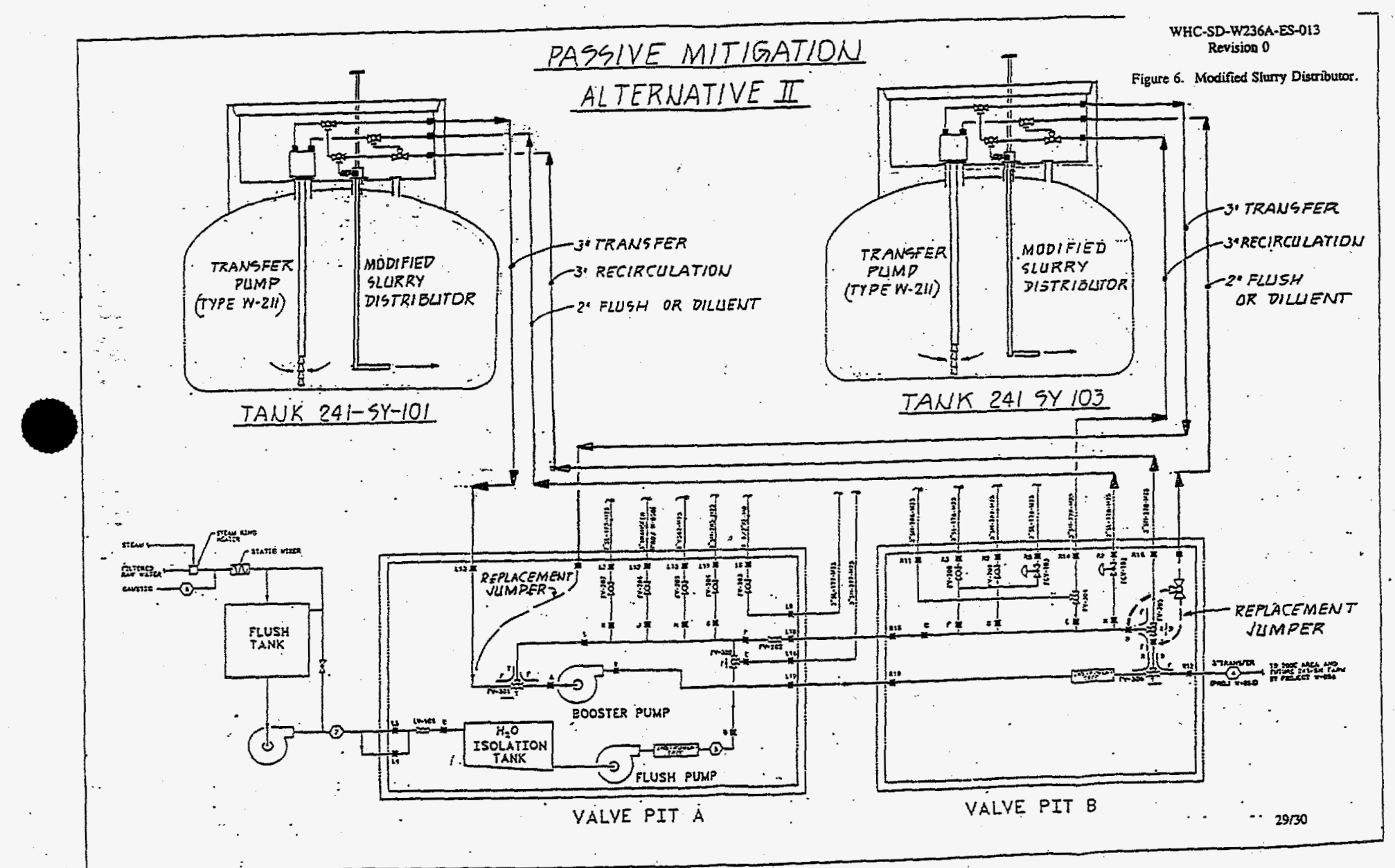


4.2.3.1 Operations Description. The operation is initiated by using the transfer pump to remove slurry from the conconvective layer in the tank. Once mobilized through the pump, the slurry is conditioned with the diluent and internally recirculated through pump and valve pits back through the slurry distributor into the tank. The initial operation would be limited in added diluent by the available tank space. Once the required waste specification has been achieved, a transfer would be initiated to remove a specified quantity of waste for additional diluent to be added to the tank. Diluent is then added via the slurry distributor to reach the prescribed in-tank dilution ratio. Following the diluent addition the tank is again mixed via the transfer pump/slurry distributor to recirculate and further disperse the diluent. This operation would be discontinued once it is determined that the waste has been sufficiently diluted to mitigate the gas retention condition.

4.2.3.2 Life-Cycle Cost. The rough order of magnitude cost estimate for Alternative 2 was developed using input from the Tank Waste Safety Program, Project W-211, and Project W-320. The Project W-211 cost estimate was revised (estimate File No. W211PAA4) by deleting the installation of new jet mixer pumps and the estimate includes providing a transfer, dilution, and flushing system as identified in Section 4.2 above. Also, costs were obtained from the Project W-211 Initial Tank Retrieval Systems Conceptual Design Report; WHC-SD-W211-CDR-002, Rev. 0 (Rieck 1994) for modifications being planned for tank 241-SY-103. 'These modifications would cover transfer pump installation and connection to the dilution system previously provided to Tank 241-SY-101. Costs associated with the design, procurement/fabrication, and installation of the modified slurry distributor were developed using the cost estimate, File No. W320PBB4, for Project W-320, Tank 241-C-106 Waste Retrieval.

Table 8 provides the ROM cost breakdown for Alternative 2. Table 9 summarizes the costs for the systems being provided to derive a total life-cycle cost. Cost data to assemble the ROM cost estimates are as identified in the notes for Table 8. 
Table 8. Life-Cycle Cost for Passive Mitigation, Alternative 2.

\begin{tabular}{|c|c|c|c|}
\hline & Dilution syste & m (\$ MApdified slu & $\operatorname{tor}^{3}$ \\
\hline 241 & $1 \longdiv { S Y - 1 0 1 ^ { 1 } }$ & 241-\$夕Y-1032 & \\
\hline Project & & & \\
\hline Engineering & 5.3 & 1.7 & 1.0 \\
\hline Procurement and Fabrication & 9.9 & 1.6 & 0.5 \\
\hline Construction & 6.9 & 3.1 & 0.5 \\
\hline Operating Costs & & & \\
\hline Installation in-tank equipment & $1.0^{4}$ & $1.0^{(4)}$ & (4) \\
\hline Post Installation Costs & $2.0^{5}$ & & \\
\hline Spares & $\mathrm{n} / \mathrm{a}$ & $\mathrm{n} / \mathrm{a}$ & $\mathrm{n} / \mathrm{a}$ \\
\hline Replacements/Equipment & $\mathrm{n} / \mathrm{a}$ & $\mathrm{n} / \mathrm{a}$ & $\mathrm{n} / \mathrm{a}$ \\
\hline $\begin{array}{l}\text { Disposal of In-Tank } \\
\text { Equipment }\end{array}$ & $0.4^{6}$ & $0.4^{(6)}$ & $0.7^{(6)}$ \\
\hline $\begin{array}{l}\text { Safety Reviews and Design } \\
\text { Reviews }\end{array}$ & 2.3 & 0.6 & 1.5 \\
\hline $\begin{array}{l}\text { Total (rounded to the nearest } \\
\text { million) }\end{array}$ & 28.0 & 8.0 & 4.0 \\
\hline
\end{tabular}

${ }^{1}$ Project costs for 241-SY-101 transfer system as scoped by Project W-211. Cost associated with the safety reviews and design reviews are tabulated at the end of the table.

${ }^{2}$ Project costs for the 241-SY-103 transfer system upgrades to 241-SY-101 system.

${ }^{3}$ Costs are projected from Project W-320 cost estimates. Costs include a control system.

"Costs for installation of two transfer pumps and to modified slurry distributors. It is assumed that the slurry distributors would be installed at the same time the pumps are installed.

${ }^{5}$ Cost covers average of 10 FTEs for one year and miscellaneous cost of $\$ 500,000$. One FTE is $\$ 150,000 /$ year. ${ }^{6}$ Cost covers two disposal containers for removal of two modified slurry distributors and two transfer pumps after mitigation activities are completed. The cost includes operations support for the removal, field packaging, and delivery to solid waste disposal (see Appendix.A, Disposal Cost Assumptions). 
WHC-SD-W236A-ES-013

Revision 0

Table 9. Summary of Life-Cycle Costs for Passive Mitigation, Alternative 2.

\begin{tabular}{|l|c|}
\hline \multicolumn{1}{|c|}{ System } & $\begin{array}{c}\text { Life-cycle cost } \\
\text { (\$ millions) }\end{array}$ \\
\hline 241-SY-101 dilution system & 28 \\
\hline 241-SY-103 dilution system & 8 \\
\hline Modified slurry distributors & 4 \\
\hline Total & 40 \\
\hline
\end{tabular}

4.2.3.3 Discussion. Passive mitigation using waste recirculation via slurry distributors and transfer pumps relies on slurry distributor technology to mobilize and mix tank waste layers, and coupled with waste dilution achieves an in-tank waste state that cannot generate GREs.

Alternative 2 carries only the cost of transfer pumps and a slurry distributor system used for both waste recycle and mixing and waste transfer following mixing; these are more economical from both a capital and operational standpoint. A dilution and diluent preparation/feed system and some pit modifications are also required.

The principle benefit of Alternative 2 is that it is not burdened by costly jet mixer pumps and their operation, and thus the overall cost is comparatively low. However, there are little operational data on the mixing performance with submerged slurry distributors used in this application. This uncertainty is somewhat comparable to that associated with jet mixer pumps used to "mix" a diluted tank. Another uncertainty is that dilution has not been operationally demonstrated to be a successful mitigation mechanism and the degree of mixing required following dilution has not been quantified.

Alternative 2 offers a mitigation strategy independent of jet mixer pumps, is considerably more economical, and eliminates GREs. However, its success relies on the validity of the laboratory data developed on dilution and the ability of submerged slurry distributors to achieve waste mixing comparable to jet mixer pumps. 
WHC-SD-W236A-ES-013

Revision 0

This page intentionally left blank. 
WHC-SD-W236A-ES-013

Revision 0

\subsection{REFERENCES}

Allemann, R. T., Z. I. Antoniak, W. D. Chvala, L. E. Efferding, J. G. Fadeff, J. R. Friley, W. B. Gregory, J. D. Hudson, J. J. Irwin, N. W. Kirch, T. E. Michener, F. E. Panisko, C. W. Stewart, and B. M. Wise, 1994, Mitigation of Tank 241-SY-101 by Pump Mixing: Results of Testing Phase $A$ and B, PNL-9423, Pacific Northwest Laboratory, Richland, Washington.

Awadalla, N. G., 1994, Position Paper, Need for Additional Waste Storage Capacity and Recommended Path Forward for Project W-236A, Multi-Function Waste Tank Facility, WHC-SD-W236A-ER-011, Rev. 0, Westinghouse Hanford Company, Richland, Washington.

Benegas, T. R., 1992, Final Design Report for Mitigation Mixing Test of Hanford Site Hydrogen Gas-Generating Waste Tank SY 101, WHC-SD-WM-ER-158, Rev. 0, Westinghouse Hanford Company, Richland, Washington.

Benegas, T. R., 1995, Spare Mitigation/Retrieval Mixer Pump, WHC-SD-WM-FDC-036, Rev. 0, Westinghouse Hanford Company, Richland, Washington.

Hudson, J. D., G. S. Barney, P. R. Bredt, A. R. Felmy, D. L. Herting, A. P. Larrick, D. A. Reynolds, C. W. Stewart, J. M. Tingey, and D. S. Trent, 1995, An Assessment of the Dilution Required to Mitigate Hanford Tank 241-SY-101, PNL-10417, Pacific Northwest Laboratory, Richland, Washington.

Jordan, K. N., 1994, Tank Waste Remediation System, Multiyear Work Plan, WHC-SP-1101, Westinghouse Hanford Company, Richland, Washington.

LANL, 1994, A Safety Assessment for Proposed Pump Mixing Operations to Mitigate Episodic Gas Releases in Tank 241-SY-101: Hanford Site, Richland, Washington, LA-UR-92-3196, Rev. 19, Los Alamos National Laboratory, Los Alamos, New Mexico.

Rieck, C. A., 1994, Project W-211 Initial Retrieval Systems Conceptual Design Report, WHC-SD-W211-CDR-002, Rev. 0, Westinghouse Hanford Company, Richland, Washington.

Stewart, C. W., L. A. Schienbein, J. D. Hudson, E. J. Eschbach, and D. L. Lessor, 1994, Assessment of Alternative Mitigation Concepts for Hanford Flammable Gas Tanks, PNL-10105, Pacific Northwest Laboratory, Richland, Washington.

Swanson, L. M., T. W. Crawford, M. E. Johnson, and E. C. Norman, 1994, Functions and Requirements for Project W-236B, Low-Level Waste Pretreatment Module I, WHC-SD-W236B-FRD-002, Westinghouse Hanford Company, Richland, Washington. 


\section{WHC-SD-W236A-ES-013 \\ Revision 0}

Thomson, J. D., 1994, Internal Memo to L. F. Ermold, Technical Tasks - Action Plan to Support the MWTF Path Forward, September 27, 1994, Westinghouse Hanford Company, Richland, Washington. 
WHC-SD-W236A-ES-013

Revision 0

APPENDIX A

OPERATIONAL COST ASSUMPTIONS

\section{ACTIVE MITIGATION}

\section{POST INSTALLATION OPERATIONAL COSTS}

The cost for this element was developed based on the following assumptions:

- Two mitigation pumps will be in operation: one for 241-SY-101 and one for 241-SY-103. Both pumps will be controlled from one DACS. The pumps will be run on alternate days.

- Only steady-state operational resources are included. Set-up, installation, removal, or recovery from major upsets are not included.

- Staffing resources identified below do not include support for tests or aberrations to normal operations to satisfy scientific inquiry.

- Full Time Equivalent (FTE) is the average resources used during the course of one year of operation. Management support provided is for all organizations which would be involved with the annual operation.

It is additionally assumed that approximately $\$ 300,000$ per year will be expended for miscellaneous and essential materials in support of the operation. Miscellaneous and essential materials will consist of expense funded spare equipment/instrumentation, protective clothing, laundry, plastic, and solid waste generated by the operation.

Table A-1 was assembled with input provided by TWRS West Tank Operations personnel. The individuals who provided input are Ron Reed/Manager of Installation and Acceptance, Guy Bear/Manager of Test Engineering, and Gary Dunford/Manager of Waste Tanks Upgrades, Installation, and Testing. 
WHC-SD-W236A-ES-013

Revision 0

Table A-1. Staffing.

\begin{tabular}{|c|c|}
\hline Staffing (FTE) & Function/Task \\
\hline 2.0 & $\begin{array}{l}\text { Pump operators and shift supervisors. } \\
\text { Takes } 3-4 \text { hours per pump running } 20-30 \text { minutes per day. } \\
\text { Pumps will be run } 3 \text { times per week. }\end{array}$ \\
\hline 1.0 & Engineer for data review/surveillance. \\
\hline 1.0 & Cognizant engineer for pumps, operational tank farm system, and DACS operation. \\
\hline 2.0 & $\begin{array}{l}\text { Craft support. Instrument technician, electricians, and pipefitters for preventative maintenance } \\
\text { and calibration activities. }\end{array}$ \\
\hline 1.0 & $\begin{array}{l}\text { Job Control System Support. Planners, schedulers, material coordinators, and Quality Control } \\
\text { support. }\end{array}$ \\
\hline 1.0 & Health Physics Technician field support for operations and maintenance tasks. \\
\hline 1.0 & Management support for tasks. \\
\hline 1.0 & $\begin{array}{l}\text { Nuclear Safety-and Quality Assurance oversite support of safety basis for SEL, ISB, ASA, and } \\
\text { modifications resulting from USQ evaluations. }\end{array}$ \\
\hline 0.5 & Engineering Support. DACS software modifications and configuration control. \\
\hline 0.5 & $\begin{array}{l}\text { Engineering Support. Acceptance test procedures for modifications and changes to Operating } \\
\text { Procedures. }\end{array}$ \\
\hline 11.0 & Total support for normal, steady-state operation of two jet mixer pumps in SY tank farm. \\
\hline
\end{tabular}

ASA = Accelerated Safety Analysis

DACS = Digital Acquisition Control System

FTE = Full time equivalent

ISB = Interim Safety Basis

SEL = Safety Equipment List

USQ = Unreviewed safety question 


\section{WHC-SD-W236A-ES-013}

\section{Revision 0}

\section{DISPOSAL COST ASSUMPTIONS}

The disposal costs were obtained from WesTIP IV Workshop, Tank Farms Disposal of Long-Length Contaminated Equipment, WHC-SD-WM-ER-433 (Titzler 1995). The costs shown in Table A-2 account for operational and material costs to remove the Long-Length Contaminated Equipment (LLCE) form the tank and the disposal container (referred to as a High Integrity Container [HIC]). It is assumed that the required transport equipment is existing and therefore not part of the unit cost. Also not included are the charges to be incurred from Solid Waste Disposal since this rate will vary from year to year.

The current system for disposal of the equipment assumes that the equipment can be disposed of as mixed waste.

Table A-2. Disposal Costs.

\begin{tabular}{|l|c|c|}
\hline \multicolumn{1}{|c|}{ Task/Function } & $\begin{array}{c}\text { Staffing (Person } \\
\text { Weeks) }\end{array}$ & Cost (\$000) \\
\hline Job Control Support. Initiate work package. & 0.2 & 0.5 \\
\hline Identify Physical, radiological and chemical characteristics. & 2.0 & 5.0 \\
\hline Select disposal mode and equipment. & 1.0 & 2.5 \\
\hline Assemble work package. & 10.0 & 25.0 \\
\hline Review and approve work package. & 2.0 & 5.0 \\
\hline Develop schedule. & 3.0 & 7.5 \\
\hline Prepare people, equipment, and site. Includes cost of flexible & $30.0+$ material & 75.0 \\
receiver and HIC. & & 36.0 \\
\hline Retrieve LLCE and close riser. & 20.0 & 56.0 \\
\hline Insert equipment into HIC and weld end cap. & 15.0 & 37.5 \\
\hline Void fill HIC. Includes cost of void fill material. & $2.0+$ material & 20.0 \\
\hline Break down system, and clean up. & 30.0 & 5.0 \\
\hline Validate Characterization. & 0.4 & 75.0 \\
\hline Issue shipping papers. & 1.0 & 1.0 \\
\hline Transport to Solid Waste Disposal. & 2.0 & 2.5 \\
\hline Total & 118.6 & 5.0 \\
\hline
\end{tabular}

The table reflects costs per unit removed, i.e., one mixer pump, one transfer pump, one modified slurry distributor. 